\title{
Knowledge management in health: a systematic literature review
}

\author{
Elyrose Sousa Brito Rocha ${ }^{1}$ \\ Patricia Nagliate ${ }^{1}$ \\ Claudia Elisangela Bis Furlan ${ }^{1}$ \\ Kerson Rocha Jr² \\ Maria Auxiliadora Trevizan ${ }^{3}$ \\ Isabel Amélia Costa Mendes ${ }^{4}$
}

\begin{abstract}
Knowledge has been used as a resource for intelligent and effective action planning in organizations. Interest in research on knowledge management processes has intensified in different areas. A systematic literature review was accomplished, based on the question: what are the contributions of Brazilian and international journal publications on knowledge management in health? The sample totaled 32 items that complied with the inclusion criteria. The results showed that $78 \%$ of journals that published on the theme are international, $77 \%$ of researchers work in higher education and $65 \%$ have a Ph.D. The texts gave rise to five thematic categories, mainly: development of knowledge management systems in health (37.5\%), discussion of knowledge management application in health $(28.1 \%)$ and nurses' function in knowledge management
\end{abstract} $(18.7 \%)$.

Descriptors: Knowledge Management; Knowledge Management for Health Research; Human Resources; Nursing; Health Organizations.

\footnotetext{
${ }^{1}$ Doctoral students, Escola de Enfermagem de Ribeirão Preto, Universidade de São Paulo, WHO Collaborating Centre for Nursing Research Development, Brazil.

2 Post-doctoral fellow, Escola de Enfermagem de Ribeirão Preto, Universidade de São Paulo, WHO Collaborating Centre for Nursing Research Development, Brazil.

${ }^{3}$ PhD, Retired Full Professor, Escola de Enfermagem de Ribeirão Preto, Universidade de São Paulo, WHO Collaborating Centre for Nursing Research Development, Brazil.

${ }^{4}$ PhD, Full Professor, Escola de Enfermagem de Ribeirão Preto, Universidade de São Paulo, WHO Collaborating Centre for Nursing Research Development, Brazil.
}

Corresponding Author:

Isabel Amélia Costa Mendes

Universidade de São Paulo. Escola de Enfermagem de Ribeirão Preto

Departamento de Enfermagem Geral e Especializada

Av. dos Bandeirantes, 3900

Bairro: Monte Alegre

CEP: 14040-902, Ribeirão Preto, SP, Brasil

E-mail: iamendes@eerp.usp.br 


\section{Gestão do conhecimento na saúde: revisão sistemática de literatura}

O conhecimento tem sido utilizado como recurso no planejamento de ações inteligentes e eficazes nas organizações. O interesse em investigar processos de gestão do conhecimento vem se intensificando nas diversas áreas. Esta revisão sistemática da literatura foi norteada pela questão: quais as contribuições das publicações em periódicos nacionais e internacionais sobre gestão do conhecimento na saúde? A amostra totalizou 32 itens que se enquadraram nos critérios de inclusão deste estudo. Os resultados mostraram que $78 \%$ dos periódicos que publicaram sobre o assunto são internacionais, $77 \%$ dos pesquisadores atuam em ensino superior e $65 \%$ possuem título de doutor. Os textos originaram cinco categorias temáticas, sendo as principais: desenvolvimento de sistemas de gestão do conhecimento em saúde (37,5\%), discussões sobre a aplicação da gestão do conhecimento em saúde $(28,1 \%)$ e função do enfermeiro na gestão do conhecimento $(18,7 \%)$.

Descritores: Gestão do Conhecimento; Gestão do Conhecimento para a Pesquisa em Saúde; Recursos Humanos; Enfermagem; Organizações em Saúde.

\section{Gestión del conocimiento en salud: revisión sistemática de la literatura}

El conocimiento ha sido utilizado como recurso en la planificación de acciones inteligentes y eficaces en las organizaciones. El interés en investigar procesos de gestión de conocimiento se ha intensificado en diversas áreas. Fue desarrollada una revisión sistemática de la literatura, basada en la cuestión: ¿Cuáles son las contribuciones de las publicaciones en revistas brasileñas e internacionales sobre gestión de conocimiento en salud? La muestra abarcó a 32 ítems que cumplieron con los criterios de inclusión. Los resultados mostraron que el $78 \%$ de las revistas que publicaron sobre el tema son internacionales, $77 \%$ de los investigadores actúan en la educación superior y $65 \%$ tiene título de doctor. Los textos originaron a cinco categorías temáticas, siendo las principales: desarrollo de sistemas de gestión del conocimiento en salud (37,5\%), discusiones sobre la aplicación de la gestión del conocimiento en salud $(28,1 \%)$ y función del enfermero en la gestión del conocimiento $(18,7 \%)$.

Descriptores: Gestión del Conocimiento; Gestión del Conocimiento para la Investigación en Salud; Recursos Humanos; Enfermería; Organizaciones en Salud.

\section{Introduction}

Today, well-informed, demanding and more competitive persons are increasingly common. This is due to everyone's easy and fast information access. Modern technology offers access to the internet, which has facilitated the immediate information search process. As a result, this accelerated process has clearly affected different work sectors, including health.

At the same time, health system users are increasingly aware of their rights and demand better conditions and increased quality of care delivery. In this context, distinguished techniques and tools, often used in the industrial sector, have been adapted and used for the health area, particularly care and service quality ${ }^{(1)}$. Thus, one of the strategies adopted, based on large companies and industrial organizations' experiences, is to apply the concepts of learning, knowledge and competency ${ }^{(2)}$ in health institutions too.

Knowledge has been considered one of the most important resources in an organization, because it is capable of making organizational and individual actions more intelligent, efficient and effective. This stimulates the elaboration of innovative and continuously excellent products and services in terms of complexity, flexibility and creativity. 
The Knowledge Management (KM) process covers any form of managing, storing, distributing and using knowledge). This process involves the treatment of large data volumes, demanding the use of information technologies to achieve acceptable efficiency. To enhance growth, development, communication and knowledge preservation in an organization, KM allows professionals to reach rapid and assertive responses, linked with the decisions they need to take(3).

In that sense, information systems, present in many health institutions, such as e-learning, allow professionals in this area to develop tacit knowledge storage capacities, which will later be converted into explicit knowledge ${ }^{(4)}$.

Explicit knowledge comprises text represented in books and written documents, or taxonomies and rules $^{(3)}$. It is reliable, formal, systematic, easy and rapid to disseminate and connects people $e^{(4-5)}$. Tacit knowledge results from personal experience accumulated for many years $^{(4)}$, marked by intuition, good sense and insights ${ }^{(5)}$. In this type of knowledge, sharing is needed, which turns dialogue into an important learning mechanism. These two knowledge types intermingle in institutions ${ }^{(5)}$.

In Nursing, various information technology tools exist that facilitate the decision making process, including: support for evidence-based practice, best practices stored in databases, clinical databases, distance education, electronic prescriptions and files ${ }^{(6)}$. As health service managers, nurses should rapidly disseminate and share tacit and explicit knowledge with team members and other health professionals. Thus, they will contribute to enhance the team's decisionmaking skills on care actions, which will directly affect the quality of care delivery ${ }^{(2)}$.

When gaining further knowledge, nursing professionals manage to make safer and more effective decisions. This behavior leads to changes in the characteristics of the work performed, with a view to the rapid and assertive achievement of expected results ${ }^{(2)}$. For these gained results to be high-quality, however, it is important for professionals to know how to manage and use this knowledge, obtained from countless existing information sources, in a correct and competent way ${ }^{(5)}$.

Based on the above, this goal of this research is to develop a systematic literature review, guided by the following question: how do studies contribute that were published in Brazilian and international journals on Knowledge Management in Health between 2000 and 2010?

\section{Method}

A literature review is the search for information on a certain theme with a view to summarizing knowledge production on a research problem and enhancing readers' understanding of what has been published about the theme. By providing research results, this method can help professionals, researchers and students in their decision making, discovering what has been investigated about the theme(7).

This type of study can offer potential contributions and represents a valuable part of the creation and organization process of the body of knowledge on a given theme ${ }^{(8)}$. To attend to the study aims, a systematic literature review was developed according to defined criteria($^{(8-10)}$ and based on the following methodological phases: 1 . Selection of the question for the review; 2. Sample selection; 3. Definition of characteristics of sample studies, based on inclusion criteria the authors defined; 4. Analysis of results, using an adapted instrument elaborated by Polleti and Caliri(10); 5 . Discussion of results; 6 . Presentation and dissemination of results.

The inclusion criteria to define the sample in this study were: studies published between 2000 and 2010, in Brazilian and international journals; in Portuguese, English and Spanish; presenting contributions about KM in health and whose full version was available.

Publications in the sample were retrieved from the databases Virtual Health Library (BIREME) and Web of Science. The keyword "gestão do conhecimento" was used, as well as its corresponding term in English, "knowledge management".

\section{Results}

During the search process in the databases, initially 9,092 items were identified. A refined search for health research published in the years defined for this study redefined the number to 439. One of these was written in German, two were available in two databases and 299 addressed a theme different from the aim, without specific contributions on KM in health. Out of the 137 remaining studies, the full versions of 32 were located, defining the analysis sample for this review.

Publications in BIREME totaled $22 \%$ of the sample (7 items), two of which were accessed in Scielo, three in Lilacs and two in both. Most studies were found in the Web of Science. Twenty-five percent (8 items) of them were indexed in Scopus, 19\% (6 publications) in IEEE, 
three in Lippincott Williams and Wilkins, two in Biomed Central Ltd and, finally, the databases SAGE, Wiley Inter Science, E-Cam, Blackwell Publishing Ltd, Ovid's and Oxford University Press appeared with one publication each.

The mean number of publications during the study period is 2.9 per year (Table 1 ).

Table 1 - Distribution of publications per year between 2000 and 2010. Ribeirão Preto, SP, Brazil, 2010

\begin{tabular}{ccc}
\hline & \multicolumn{2}{c}{ Paper } \\
\cline { 2 - 3 } Year & No & $\%$ \\
\hline 2000 & 1 & 3.1 \\
2001 & 1 & 3.1 \\
2003 & 1 & 3.1 \\
2004 & 6 & 18.8 \\
2005 & 2 & 6.3 \\
2006 & 7 & 21.9 \\
2007 & 4 & 12.5 \\
2008 & 5 & 15.6 \\
2009 & 1 & 3.1 \\
2010 & 3 & 9.4 \\
Total & 1 & 3.1 \\
\hline
\end{tabular}

Out of the 32 studies that were part of the sample, $78.1 \%$ were published in international journals. Among these, publications in Transactions on Information Technology in Biomedicine (18.8\%) predominated, followed by the International Journal of Medical Informatics with $15.6 \%$ (Table 2 ).

It is important to highlight that, among Brazilian journals, the Latin American Journal of Nursing appeared with the largest number of publications on the theme (6.3\% of the total).

Table 2 - Distribution of publications according to source. Ribeirão Preto, SP, Brasil, 2010

\begin{tabular}{lcc}
\hline \multicolumn{1}{c}{ Source } & Frequency & $\%$ \\
\hline International & & \\
IEEE Transactions on Information Technology in & 6 & 18.8 \\
$\begin{array}{l}\text { Biomedicine } \\
\text { International Journal of Medical Informatics }\end{array}$ & 5 & 15.6 \\
Journal of Nursing Administration & 2 & 6.3 \\
Advanced Access Publication & 1 & 3.1 \\
Annals of Occupational Hygiene & 1 & 3.1 \\
Biotechnology Advances & 1 & 3.1 \\
British Medical Journal & 1 & 3.1
\end{tabular}

Table 2 - (continuation)

\begin{tabular}{lcc}
\hline \multicolumn{1}{c}{ Source } & Frequency & $\%$ \\
\hline Canadian Medical Association Journal & 1 & 3.1 \\
Clinical Nurse Specialist & 1 & 3.1 \\
Comput Meth Programs Biomed & 1 & 3.1 \\
Health & 1 & 3.1 \\
Journal of the American Society for Information & 1 & 3.1 \\
Science and Technology & 1 & 3.1 \\
Journal of Biomedical Informatics & 1 & 3.1 \\
Journal of Evaluation in Clinical Practice & 1 & 3.1 \\
Medical Informatics and Decision Making & 25 & 77.9 \\
Total International & & \\
Brazilian & 2 & 6.3 \\
Revista Latino-Americana de Enfermagem & 1 & 3.1 \\
Ciência e Saúde Coletiva & 1 & 3.1 \\
Master's Thesis & 1 & 3.1 \\
Revista de Administração Contemporânea & 1 & 3.1 \\
Revista Brasileira de Enfermagem & 1 & 3.1 \\
Saúde e Sociedade & 7 & 21.9 \\
Total Brazilian & 32 & 100 \\
\hline Total & &
\end{tabular}

The number of authors in the analyzed studies totaled 92. Another result that is highlighted is distributed in Table 3 and refers to these researchers' degrees. These data demonstrate the predominance of Ph.D.'s, representing 65.2\%.

Out of 92 researchers, $70(76.1 \%)$ are active in higher education institutions, 21 (22.9\%) in research institutions or centers and only $1 \%$ in health institutions.

Although we were unable to identify the degrees of $4.4 \%$, most authors are inserted in the academic context and affiliated with research centers and groups.

Table 3 - Distribution of publications according to authors' degrees. Ribeirão Preto, SP, Brazil, 2010

\begin{tabular}{lcc}
\hline \multicolumn{1}{c}{ Degree } & N & \% \\
\hline Ph.D. & 60 & 65.2 \\
M.Sc. & 22 & 23.9 \\
Ph.D. student & 2 & 2.1 \\
Undergraduates & 4 & 4.4 \\
Not identified & 4 & 4.4 \\
Total & 92 & 100 \\
\hline
\end{tabular}

Out of 92 researchers in the sample, the majority $(39.1 \%)$ is located in the United States, followed by Brazil (17.4\%) and England (16.3\%). (Table 4) 
Table 4 - Distribution of studies according to authors' country of origin. Ribeirão Preto, SP, Brazil, 2010

\begin{tabular}{lcc}
\hline \multicolumn{1}{c}{ Country } & No & $\%$ \\
\hline USA & 36 & 39.1 \\
Brazil & 16 & 17.4 \\
England & 15 & 16.3 \\
Canada & 10 & 10.9 \\
Australia & 5 & 5.5 \\
Greece & 3 & 3.3 \\
Italy & 2 & 2.1 \\
Malaysia & 2 & 2.1 \\
China & 1 & 1.1 \\
India & 1 & 1.1 \\
Poland & 1 & 1.1 \\
Total & 92 & 100 \\
\hline
\end{tabular}

Table 5 displays the frequency of research types and the current status of publications on $\mathrm{KM}$ in health that comprised the study sample. Descriptive studies are most frequent (34.4\%), followed by theoretical reflections $(18.8 \%)$ and critical analyses (15.6\%).

Table 5 - Frequency distribution of research regarding to study type. Ribeirão Preto, SP, Brazil, 2010

\begin{tabular}{lcc}
\hline \multicolumn{1}{c}{ Study type } & Frequency & $\%$ \\
\hline Descriptive study & 11 & 34.4 \\
Theoretical reflection & 6 & 18.8 \\
Critical analysis & 5 & 15.6 \\
Exploratory and descriptive & 4 & 12.5 \\
Bibliographic review & 3 & 9.4 \\
Case study & 2 & 6.2 \\
Ethnographic study & 1 & 3.1 \\
Total & 32 & 100 \\
\hline
\end{tabular}

The analysis of selected publications concerning the contributions on $\mathrm{KM}$ in health revealed five categories, divided per theme: development of $\mathrm{KM}$ systems in health (37.5\% of studies), discussions on $\mathrm{KM}$ application in health (28.1\%), nurse's function in $\mathrm{KM}$ (18.7\%), assessment of KM in health institutions (9.4\%) and transformation of tacit and explicit knowledge in knowledge practices in health (6.3\%).

\section{Discussion}

In the last decade, papers of the theme have been published in all years. The year 2005 shows the largest number of items (21.9\%), followed by 2003 with $18.8 \%$ and 2007 with $15.6 \%$ (Table 1 ). These results are in line with other studies that highlight that, recently, studies on KM have intensified(11), focusing on the need to understand how organizations work with knowledge to develop new products, new processes and new forms or more flexible organizational arrangements with a view to a greater sustainable competitive advantage.

KM should increasingly be part of hospital organizations' strategies, as the growing valuation of knowledge can be considered unavoidable(12). The investment flow in people and the full use of company participants' intelligence is disseminated around the world and converges towards a knowledge-based economy as well. In function of work management changes, the valuation of human capital has gained great prestige in the last ten years. It is related with practices and debates on the segmentation of the job market, polytechnics, polyvalence, flexibility and total quality. It is also part of discussions on neoliberalism in education and on the role of workers' education as an emancipating elements that conditions actions inside institutions ${ }^{(13)}$.

These variables may have influenced research on the $\mathrm{KM}$ process in the last ten years and its importance in the health sector.

More recently, professionals in this area may be discovering the importance of knowledge management in the institutions they work at; after all, their actions constantly involve human relations and the communication process. Besides, the implementation of this process entails sustainable advantages that are hard to imitate, because it is unique in each organization. It is based on the people who work at the company and not on physical resources, which are easy to imitate and less flexible.

Another result found refers to a lesser number of publications by professionals working in health institutions. We believe that research should be inserted not only in students and teachers' daily reality, but should involve health professionals directly involved in patient care. Research should be stimulated at health services too, involving professionals working at these places, with a view to expanding knowledge and enhancing approximations between care, research and teaching. We agree that the integration of the university into health services enhances recycling and access to scientific innovations ${ }^{(14)}$.

KM's contributions in health resulted in five theme categories. The first refers to the development of $\mathrm{KM}$ systems in health (37.5\% of studies).

The need to develop information technology solutions, using KM to capture experienced professionals' 
tacit knowledge, is one of the aspects explored in the first category ${ }^{(15)}$. Another study appoints barriers to information collection, such as the lack or inadequacy of equipment, flaws in communication services, prejudices, conflicts of interest and inadequate self-assessment of knowledge and skills by professionals ${ }^{(16)}$.

On the other hand, data mining is cited as a solution that permits exploring all available knowledge in the organization for the intelligent recovery of relevant data and their distribution among different health care providers $^{(3)}$.

The use of KM as a resource to support decision making in health has been explored(17-20), including approaches to the development of decision support systems and the characterization of the current state of using KM tools and techniques in clinical decisions. The development of a decision support system in the context of neonatal intensive care units through the use of artificial intelligence techniques has also been discussed(21), as well as in clinical contexts, integrated in electronic patient file systems ${ }^{(22)}$.

One KM model was constructed based on an analysis of interprofessional literature about KM, also considering interview transcripts and observational data collected based on health practices ${ }^{(23)}$.

Authors describe (24) a KM system based on key performance indicators, constructed based on the use of the Balanced Score Card and techniques to guarantee quality in health.

Through a portal that integrates organizational knowledge, people who use the knowledge, the KM process and information technology, facilitating evidence-based Chinese medicine ${ }^{(25)}$, it was explored how the knowledge was organized and coded for storage in a database and how the system's architecture was developed.

The second category joined publications that present discussions about KM in health: application of KM in occupational safety and health, addressing gaps in KM in this area; dangers and flaws in KM practices in primary care; discussion about the theme as an innovative and important strategy for the economy of current health institutions; use of the internet and evidence-based clinical decision making as complementary forces in the development of efficient $\mathrm{KM}$, resulting in rapid, efficient and low-cost decision making and facilitating communication in the health care process ${ }^{(1,26-33)}$.

Studies on nurses' function in KM comprised the third category and highlight that these professionals' position includes them among the expectations of institutional managers and frontline workers, holding them accountable for the management of personnel and, consequently, of human capital. In view of the importance this is granted, publications attempt to get a better understanding of KM strategies for this professional's function ${ }^{(2,5,13,34-36)}$.

Some nursing activities contribute to the organization's success in the transformation process of tacit into explicit knowledge, such as the elaboration and organization of documents, manuals, protocols and routines regarding the activities present in their daily professional reality(2). As a result of this activity, accumulated knowledge can allow all professionals to do something easily, efficiently and safely. Another activity the authors mentioned refers to the conversion of explicit into tacit knowledge, in which nurses develop formal training applications, based on manuals and books, which are shared for employees to start internalizing and using them to broaden and reformulate their tacit knowledge.

Nurses should be prepared to assess the technological, organizational and human resources required for the development of $\mathrm{KM}$, and to develop competences like knowledge, skills, attitudes and values, so that they are capable of planning, organizing, directing and controlling KM in the organizations where they are responsible for human capital ${ }^{(13)}$.

Papers in the fourth category, called: "assessment of KM in health institutions", appoint the importance and need to use theoretical models and programs/software to assess $\mathrm{KM}$ at these institutions.

According to the publications, elements like: the administrative decision-management process, communication system and enculturation collaborate towards the implementation and assessment of $\mathrm{KM}^{(37)}$, which strengthens health professionals' confidence in the use of these tools for their decision making. No KM assessment system will be useful for decision making, however, if its data and results cannot be compared with those of other health institutions ${ }^{(12)}$.

Therefore, health institution managers are responsible for comparing current data and results with those of previous periods, and also with those of other institutions, as the entire KM assessment system should be adapted to end users, so that information management can emphasize the knowledge flow, change and control(12).

Hence, knowledge production and appropriation are socially distributed for the further implementation of systematic analysis. This process is the essence of these 
information systems and reinforces the importance of a KM system, facilitating access to innovation (38).

The fifth category: "transformation of tacit and explicit knowledge in health knowledge practices", indicates the importance of sharing knowledge through communities of practice, guidelines, manuals, and of using them in care practice through Evidence-Based Practice (EBP).

We know that evidence results from gross data and that their treatment is a prerequisite for the adoption of evidence-based clinical practice ${ }^{(39)}$. Incorporating EBP into practical reality is one of the main challenges health professionals face ${ }^{(40)}$, even if they are aware that the application of evidence is important to improve the quality of care delivery. That is so because the main decisions taken in health organizations are based on nonsystemized evidence, without a profound assessment of the results found ${ }^{(1)}$.

Therefore, one factor that should be considered is health professionals' lack of inquiries about the validity of information used for decisions ${ }^{(1,41)}$, deriving from health managers' lack of training and experience to cooperate with researchers in the area, from greater commitment to the values of applied research, as well as from the lack of an investment policy in human assets ${ }^{(42)}$, besides insufficient training to make evidence-based strategic decisions $^{(1)}$.

Besides these issues, few professionals considered that research results significantly influence their care practice and, also, few of them perceived scientific knowledge development as a cause of strong impact on support for decision making in their area(43). Hence, another factor that directly influences these data is professionals' lack of skills to access databases in search of information and knowledge databases ${ }^{(1)}$.

The studies analyzed in this category reinforce the importance of seeking scientific studies to support their health practices, as well as of using and transforming information and tacit and explicit knowledge into practices that can socialize them to other health professionals at the institution, through manuals, orientations and access to communities of practice. This process aims to make knowledge accessible to all stakeholders in care and assistance to people ${ }^{(4,44)}$.

\section{Conclusion}

The analyzed publications point towards health professionals' current concern with enhancing growth, development, communication and preservation of knowledge inside institutions. After all, KM permits the achievement of rapid and assertive responses in decision making in clinical practice.

The studies in this review suggest a peculiarly complex scenario in the corporate world and in society in general. Global economic and social phenomena are responsible for restructuring institutional environments, also in the health sector. Economic globalization, driven by information and communication technologies, are a reality, and it is in this context that knowledge management turns into a strategic resources for the lives of health institutions and the people working there.

\section{References}

1. Borba GS, Kliemann Neto FJ. Gestão Hospitalar: identificação das práticas de aprendizagem existentes em hospitais. Saúde Soc. 2008;17(1):44-60.

2. Shinyashiki GT, Trevizan MA, Mendes IAC. Sobre a criação e a gestão do conhecimento organizacional. [About the creation and management of organizational knowledge]. Rev. Latino-Am. Enfermagem. 2003;11(4):499-506.

3. Montani S, Bellazzi R. Supporting decisions in medical applications: the knowledge management perspective. Int J Med Inform. 2002;68(1-3):79-90.

4. Sandars J, Heller R. Improving the implementation of evidence-based practice: a knowledge management perspective. J Eval Clin Pract. 2006;12(3):341-6.

5. Mendes IAC. Organizational learning and knowledge management: a challenge we must face [Editorial]. Rev. Latino-Am. Enfermagem. 2003;11(3):269-73.

6. Simpson RL. Information technology: building nursing intellectual capital for the information age. Nurs Adm Q. 2007;31(1):84-8.

7. Polit DF, Hungler BP. Fundamentos de pesquisa em enfermagem. 4a ed. Porto Alegre: Artes Médicas; 2004. 8. Ganong LH. Integrative reviews of nursing research. Res Nurs Health. 1987;10(1):1-11.

9. Poletti NAA. O cuidado de enfermagem a pacientes portadores de feridas crônicas [Dissertação de Mestrado]. Ribeirão Preto: Escola de Enfermagem de Ribeirão Preto da Universidade de São Paulo; 2000.

10. Poletti NAA, Caliri MHL, Simão $C D$, Soares $R$, Juliani KB, Tácito VE. Feridas malignas: uma revisão de literatura. Rev Bras. Cancerol. 2002;48(3):411-7.

11. Silva LS. Gestão do conhecimento: uma revisão crítica orientada pela abordagem da criação do conhecimento. Ci Inf. 2004;33(2):143-51. 
12. Colauto RD, Beuren IM. Proposta para Avaliação da Gestão do Conhecimento em Entidade Filantrópica: - Caso de uma Organização Hospitalar. RAC. 2003;7(4):163-85.

13. Ruthes RM, Cunha ICKO. Competências do enfermeiro na gestão do conhecimento e capital intelectual. Rev Bras Enferm. 2009;62(6):901-5.

14. Mendes IAC, Godoy S, Silva EC, Seixas CA, Nogueira MS, Trevizan MA. Educação permanente para profissionais de saúde: a mediação tecnológica e a emergência de valores e questões éticas. Enferm Global. 2007;10:1-8.

15. Abidi SSR, Cheah YN, Curran J. A Knowledge Creation Info-Structure to Acquire and Crystallize the Tacit Knowledge of Health-Care Experts. IEEE Trans Inf Technol Biomed. 2005;9(2):193-204.

16. Revere D, Turner AM, Madhavan A, Rambo N, Bugni PF, Kimball $A$, et al. Understanding the information needs of public health practitioners: A literature review to inform design of an interactive digital knowledge management system. J Biomed Inform. 2007;40(4):410-21.

17. Abidi SSR. Knowledge management in healthcare: towards 'knowledge-driven' decision-support services. Int J Med Inform. 2001;63(1-2):5-18.

18. Kalogeropoulos DA, Carson ER, Collinson PO. Towards knowledge-based systems in clinical practice: Development of an integrated clinical information and knowledge management support system. Comput Methods Programs Biomed. 2003;72(1):65-80.

19. Canongia C. Synergy between Competitive Intelligence ( $\mathrm{CI})$, Knowledge Management (KM) and Technological Foresight (TF) as a strategic model of prospecting - The use of biotechnology in the development of drugs against breast cancer. Biotechnol Adv. 2007;25(1):57-74.

20. Sittig DF, Wright A, Simonaitis L, Carpenter JD, Allen $\mathrm{GO}$, Doebbeling $\mathrm{BN}$, et al. The state of the art in clinical knowledge management: An inventory of tools and techniques. Int J Med Inform. 2010;79(1):44-57.

21. Frize M, Yang L, Walker RC, O'Connor AM. Conceptual Framework of Knowledge Management for Ethical Decision-Making Support in Neonatal Intensive Care. IEEE Trans Inf Technol Biomed. 2005;9(2):205-15.

22. Downing GJ, Boyle SN, Brinner KM, Osheroff JA. Information management to enable personalized medicine: stakeholder roles in building clinical decision support. BMC Med Inform Decis Mak. 2009;9:44.
23. Orzano AJ, McInerney $C R$, Scharf $D$, Tallia AF, Crabtree BF. A Knowledge Management Model: Implications for Enhancing Quality in Health Care. ] Am Soc Inf Sci Technol. 2008;59(3):489-505.

24. Berler A, Pavlopoulos S, Koutsouris D. Using Key Performance Indicators as Knowledge-Management Tools at a Regional Health-Care Authority Level. IEEE Trans Inf Technol Biomed. 2005;9(2):184-92.

25. Yang AW, Allan G, Li CG, Xue CC. Effective Application of Knowledge Management in Evidence-based Chinese Medicine: A Case Study. Evid Based Complement Alternat Med. 2009;6(3):393-8.

26. Schulte PA, Lentz TJ, Anderson VP, Lamborg AD. Knowledge Management in Occupational Hygiene: The United States Example. Ann Occup Hyg. 2004;48(7):583-94.

27. Gabbay J, le May A, Jefferson H, Webb D, Lovelock R, Powell $\mathrm{J}$, et al. A case study of knowledge management in multiagency consumer-informed 'communities of practice': implications for evidence based policy development in health and social services. Health. (London) 2003;7(3):283-310.

28. Shirey MR. Book review: Knowledge Management. An Innovative Strategy for the Future. J Nurs Adm. 2007;37(1):5-9.

29. Jadad AR, Haynes RB, Hunt D, Browman GP. The Internet and evidence-based decision-making: a needed synergy for efficient knowledge management in health care. CMAJ. 2000;162(3):362-5.

30. Bali RK, Feng DD, Burstein F, Dwivedi AN. Guest Editorial Introduction to the Special Issue on Advances in Clinical and Health-Care Knowledge Management. IEEE Trans Inf Technol Biomed. 2005;9(2):157-61.

31. Dawes M, Sampson U. Knowledge management in clinical practice: a systematic review of information seeking behavior in physicians. Int J Med Inform. 2003;71(1):9-15.

32. Lorence DP, Churchill R. Clinical knowledge management using computerized patient record systems: is the current infrastructure adequate? IEEE Trans Inf Technol Biomed. 2005;9(2):283-8.

33. Kisilowska M. Knowledge management prerequisites for building an information society in healthcare. Int J Med Inform. 2006;75(3-4):322-9.

34. Ghosh B, Scott JE. Comparing knowledge management in health-care and technical support organizations. IEEE Trans Inf Technol Biomed. 2005;9(2):162-8. 
35. Johnson JE. Nursing research: thoughts on professional obligation, discipline and knowledge management. J Nurs Adm. 2006;36(5):221-3.

36. Barton AJ. Knowledge Management and the Clinical Nurse Specialist. Clin Nurse Spe. 2009;23(3):123-4.

37. Reis WG. Gestão do conhecimento e cultura organizacional: um estudo de caso na Fiocruz-Bahia [Dissertação de Mestrado Profissional em Saúde Pública]. Rio de Janeiro: Centro de Pesquisas Aggeu Magalhães da Fundação Oswaldo Cruz; 2007.

38. Maia PRS, Novak FR, Almeida JAG, Silva DA. Sistema de gestão do conhecimento para Rede Nacional de Bancos de Leite Humano. Ciênc Saúde Coletiva. 2005;10(Suppl):121-32.

39. Doremus HD, Michenzi EM. Data quality: an illustration of its potential impact upon a diagnosis related group's case mix index and reimbursment. Med Care. 1993;21(10):1001-11.

40. Blidner I, Lemieux-Charles L, McGuire W. Building interorganizational knowledge for evidence based health system change. Health Care Manage Rev. 2002 Summer;27(3):48-59.

41. Kovner AR, Elton JJ, Billings J. Evidence-based management. Front Health Serv Manage. 2000 Summer;16(4):3-24.

42. Trevizan MA, Mendes IAC, Mazzo A, Ventura CAA. Investment in nursing human assets: education and minds of the future. Rev. Latino-Am. Enfermagem. 2010;18(3):467-71.

43. Niedzwiedzka BM. Barriers to evidence-based decision making among polish healthcare managers. Health Serv Manage Res. 2003;16(2):106-15.

44. Gabbay J, le May A. Evidence based guidelines or collectively constructed "mindlines?" Ethnographic study of knowledge management in primary care. BMJ.

2004;329(7473):1013. 